\title{
Biallelic TET2 mutation sensitizes to 5'-azacitidine in acute myeloid leukemia
}

\section{Short title: Biallelic TET2 mutation sensitizes to 5'-Aza}

Friedrich Stölzel ${ }^{1 \dagger^{*}}$, Sarah E. Fordham ${ }^{2 \dagger}$, Wei-Yu Lin ${ }^{2 \dagger}$, Helen Blair ${ }^{2}$, Claire Elstob ${ }^{2}$, Devi Nandana $^{2}$, Brigitte Mohr ${ }^{1}$, Leo Ruhnke ${ }^{1}$, Desiree Kunadt ${ }^{1}$, Claudia Dill ${ }^{1}$, Daniel Allsop ${ }^{2}$, Rachel Piddock $^{2}$, Emmanouela-Niki Soura ${ }^{2}$, Catherine Park ${ }^{2}$, Mohd Fadly², Thahira Rahman ${ }^{2}$, Abrar Alharbi $^{2}$, Manja Wobus ${ }^{1}$, Heidi Altmann ${ }^{1}$, Christoph Röllig ${ }^{1}$, Lisa Wagenführ ${ }^{1}$, Gail L. Jones ${ }^{3}$, Tobias Menne ${ }^{3}$, Graham H. Jackson ${ }^{3}$, Helen J. Marr ${ }^{3}$, Jude Fitzgibbon ${ }^{4}$, Kenan Onel ${ }^{5}$, Manja Meggendorfer ${ }^{6}$, Olaf Heidenreich ${ }^{2}$, Torsten Haferlach ${ }^{6}$, Sara Villar ${ }^{7}$, Beñat Ariceta ${ }^{8,9}$, Rosa Ayala Diaz ${ }^{10}$, Felipe Prosper ${ }^{7}$, Pau Montesinos ${ }^{11}$, Joaquin Martinez-Lopez ${ }^{10}$, Martin Bornhäuser $^{1,12}$ and James M. Allan ${ }^{2 *}$

${ }^{1}$ Medizinische Klinik und Poliklinik I, Universitätsklinikum Dresden, TU Dresden, Dresden, Germany.

${ }^{2}$ Newcastle Centre for Cancer, Newcastle University, Newcastle Upon Tyne, UK.

${ }^{3}$ Department of Hematology, Freeman Hospital, Newcastle upon Tyne, UK.

${ }^{4}$ Barts Cancer Institute, Queen Mary University of London, London, UK.

${ }^{5}$ Icahn School of Medicine at Mount Sinai, New York, USA.

${ }^{6}$ MLL Munich Leukemia Laboratory, Munich, Germany.

${ }^{7}$ Department of Hematology, Clínica Universidad de Navarra, IdISNA, Pamplona, Spain

${ }^{8}$ Hematological Diseases Laboratory, CIMA LAB Diagnostics, University of Navarra, 31008

Pamplona, Navarra, Spain.

${ }^{9}$ Navarra Institute for Health Research (IdiSNA), 31008 Pamplona, Navarra, Spain.

${ }^{10}$ Hematology Department, Hospital 12 de Octubre i+12, CNIO, Complutense University, Madrid, Spain.

${ }^{11}$ Hospital Universitario y Politécnico La Fe, Valencia, Spain.

${ }^{12}$ National Center for Tumor Diseases, Dresden, Germany.

${ }^{\dagger}$ Joint lead authors.

*Corresponding authors: James M Allan, Newcastle Centre for Cancer, Newcastle University, Newcastle Upon Tyne, UK; e-mail: james.allan@ @ewcastle.ac.uk; phone: +44 (0)191 208 4435; fax: +44 (0)191 208 4301. Friedrich Stölzel, Medizinische Klinik und Poliklinik I, Universitätsklinikum Dresden, TU Dresden, Dresden, Germany; e-mail:

friedrich.stoelzel@uniklinikum-dresden.de

Abstract word count -245

Text word count -3931

Figure count -6

Reference count -47 
medRxiv preprint doi: https://doi.org/10.1101/2021.07.14.21259597; this version posted July 18, 2021. The copyright holder for this preprint (which was not certified by peer review) is the author/funder, who has granted medRxiv a license to display the preprint in perpetuity.

It is made available under a CC-BY 4.0 International license .

\section{Key Points}

- Mutant TET2 allele dosage affects response to 5'-azacitidine in acute myeloid leukemia in vitro and in a xenograft model.

- Our data highlight the importance for screening of biallelic mutations to predict response to therapy in acute myeloid leukemia. 
medRxiv preprint doi: https://doi.org/10.1101/2021.07.14.21259597; this version posted July 18, 2021. The copyright holder for this preprint (which was not certified by peer review) is the author/funder, who has granted medRxiv a license to display the preprint in perpetuity.

It is made available under a CC-BY 4.0 International license.

\begin{abstract}
Precision medicine can significantly improve outcomes for cancer patients, but implementation requires comprehensive characterization of tumor cells to identify therapeutically exploitable vulnerabilities. Here we describe somatic biallelic TET2 mutation (focal deletion and nonsense mutation) in an elderly patient with acute myeloid leukemia (AML) that was chemoresistant to anthracycline and cytarabine, but acutely sensitive to 5'-azacitidine (5'-Aza) hypomethylating monotherapy, resulting in long-term morphological remission (overall survival (OS) 850 days). Given the role of TET2 as a regulator of genomic methylation, we hypothesized that mutant TET2 allele dosage affects response to 5'-Aza. Using an isogenic cell model system and an orthotopic mouse xenograft, we demonstrate that biallelic TET2 mutations confer sensitivity to 5'-Aza compared to cells with monoallelic mutation. We subsequently identified 29 additional patients from the Study Alliance Leukemia biobank with chromosome 4 abnormalities and identified two further patients with complex biallelic TET2 mutations, including one with trisomy 4 , homozygosity across the long arm and an inactivating point mutation. We also screened patients recruited to the PETHEMA FLUGAZA phase 3 clinical trial and identified three patients with biallelic TET2 mutations, two of whom had responded very well to single agent 5'-Aza (OS 767 and 579 days) despite having adverse risk AML and poor performance status. Our data argue in favor of using hypomethylating agents for chemoresistant disease or as first line therapy in patients with biallelic TET2-mutated AML and demonstrate the importance of considering mutant allele dosage in the implementation of precision medicine for cancer patients.
\end{abstract}


medRxiv preprint doi: https://doi.org/10.1101/2021.07.14.21259597; this version posted July 18, 2021. The copyright holder for this preprint (which was not certified by peer review) is the author/funder, who has granted medRxiv a license to display the preprint in perpetuity.

It is made available under a CC-BY 4.0 International license.

\section{Introduction}

Acute myeloid leukemia (AML) is the exemplar of how interrogation of the somatic genome has facilitated understanding of disease pathogenesis and led to the development of novel therapies and stratified treatment approaches for some disease sub-groups ${ }^{1,2}$. Despite some success, therapeutic options for the majority of AML patients are limited and outcome remains very poor, with a 5-year overall survival (OS) of $15 \%^{3}$. Subsequent refinement of the AML genome has revealed a plethora of somatically mutated genes, including TET2 which has been associated with poor outcome $e^{1,4}$.

Given the ineffectiveness of standard chemotherapy for many patients and the resulting poor outcome it is essential to identify genetic vulnerabilities that can be therapeutically exploited using existing treatments and the expanding catalogue of new agents. To this end, we present data that biallelic TET2 mutation in AML confer sensitivity to hypomethylating chemotherapy. The TET2 enzyme catalyzes DNA demethylation by converting 5'-methylcytosine to 5'hydroxymethylcytosine, and loss or attenuation of TET2 function leads to a somatically acquired global genomic hypermethylation and transcriptional and phenotypic re-programming underpinning the development of a leukemia phenotype ${ }^{5}$. As such, it is mechanistically plausible that hypomethylating chemotherapy could be particularly effective in TET2 null AML. These data serve as a paradigm for clinical diagnostics incorporating comprehensive genomic analyses to implement first line therapies with a higher likelihood of response in patients with AML. 
medRxiv preprint doi: https://doi.org/10.1101/2021.07.14.21259597; this version posted July 18, 2021. The copyright holder for this preprint (which was not certified by peer review) is the author/funder, who has granted medRxiv a license to display the preprint in perpetuity.

It is made available under a CC-BY 4.0 International license.

\section{Methods}

\section{Patients}

AML patients with an abnormal chromosome 4 (UPN01-UPN30) were from the Study Alliance Leukemia (SAL) AML registry biobank in Dresden (Germany) which was approved by the Institutional Review Board of the Medical Faculty of Dresden (Ethikkomission der TU Dresden, Medizinische Fakultat Dresden; IRB \#EK98032010).

TET2 mutant patients over 65 years of age with newly diagnosed TET2 mutant AML (UPN3180) were from the Programa para el Estudio de la Terapeutica en Hemopatias Malignas (PETHEMA) phase 3 FLUGAZA clinical trial (NCT02319135) ${ }^{6}$, which was approved by the Institutional Review Board of Hospital Le Fe, Valencia, Spain (Eudract=2014-000319-15).

Written informed consent was received from all study participants.

\section{AML cell lines and culture}

AML cell lines were obtained from DSMZ (Braunschweig, Germany) and maintained in complete medium (CM) [RPMI1640 with $10 \% \mathrm{FBS}$ and 50 $\mathrm{g} / \mathrm{ml}$ penicillin/streptomycin] at $37^{\circ} \mathrm{C}$ in a humidified $5 \% \mathrm{CO}_{2}$ incubator. The identity of cell lines was confirmed by short tandem repeat profiling (NewGene, Newcastle University, UK) and cultures were regularly tested for mycoplasma using a MycoAlert kit (Lonza, Slough, UK).

\section{CRISPR-Cas9 TET2-targeting}

CRISPR-Cas9 TET2-targeted HEL cells were generated using a one vector system (pLV-U6gRNA/EF1a-puro-2A-Cas9-2A-GFP in lentiviral particles (Sigma-Aldrich, Dorset, UK)) with the sgRNA sequence 5'GTTTGGTGCGGGAGCGAGC3' targeting TET2 exon 6 (TET2 transcript ID ENST00000540549.5). Lentiviral particles were incubated with HEL cells (MOI 2) 
medRxiv preprint doi: https://doi.org/10.1101/2021.07.14.21259597; this version posted July 18, 2021. The copyright holder for this preprint (which was not certified by peer review) is the author/funder, who has granted medRxiv a license to display the preprint in perpetuity.

It is made available under a CC-BY 4.0 International license .

in CM supplemented with $8 \mu \mathrm{g} / \mathrm{ml}$ hexadimethrine bromide and centrifuged at $800 \mathrm{~g}$ for $30 \mathrm{~min}$ at $32^{\circ} \mathrm{C}$. Transduced cells were selected by culture in $\mathrm{CM}$ with $2 \mu \mathrm{g} / \mathrm{ml}$ puromycin then cloned by plating in soft agar [CM with $0.2 \%$ agarose]. TET2 mutation was confirmed by Sanger sequencing (exon 6) as described in supplemental methods.

\section{In vivo mouse model}

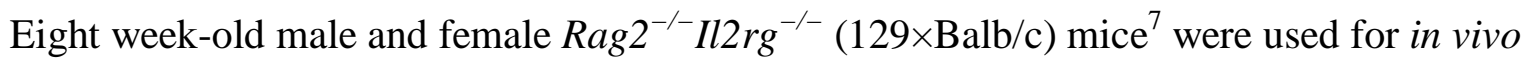
investigations (UK Home Office Project License PPL60/4552). For IF injection (on day 0), mice were anaesthetized and $5 \times 10^{5}$ cells (HEL TET2 monoallelic and HEL TET2 biallelic in a 1:1 ratio) in $20 \mu \mathrm{CM}$ were injected through the knee into the marrow cavity of the right femur. Mice were monitored for signs of disease progression and were euthanized if any tumors reached a diameter of $15 \mathrm{~mm}$, or prior to this point if any signs of animal suffering were observed (including but not limited to sustained weight loss of $15 \%$ of normal weight and reduced mobility). 5'-Aza was dissolved in sterile water and administered via intraperitoneal (IP) injection once daily starting on day 28 for 5 days at $5 \mathrm{mg} / \mathrm{kg}$. Control mice received sterile water only via IP administration. Mice were euthanized on day 35 and tissues (BM from both femurs, $\mathrm{PB}$, spleen and any tumors) were harvested during post-mortem investigation. Genomic DNA was extracted using either a DNA Mini kit or DNA Micro kit (Qiagen).

\section{TET2 allele-specific qPCR assay}

A custom TaqMan SNP Genotyping assay (Applied Biosystems, CA, USA) was designed using probes that differentiate between intact wild-type (WT) TET2 sequence (HEL TET2 monoallelic clones) and TET2 sequence with a 4bp deletion generated by CRISPR-Cas9 targeting (HEL

TET2 biallelic clones). qPCR reactions were setup in triplicate and consisted of genomic DNA (50ng), primers (forward: 5'-GTGAAGAGAAGCTACTGTGTTTGGT-3', reverse: 5'- 
medRxiv preprint doi: https://doi.org/10.1101/2021.07.14.21259597; this version posted July 18, 2021. The copyright holder for this preprint (which was not certified by peer review) is the author/funder, who has granted medRxiv a license to display the preprint in perpetuity.

It is made available under a CC-BY 4.0 International license.

ACAATCACTGCAGCCTCACA-3'), fluorescent allele-specific probes (WT TET2: 5'CCAGCTCGCTCCCG-3'-VIC, 4bp deleted TET2: 5'-TGGCCAGCTCCCG-3'-FAM) and TaqMan SNP genotyping mastermix (Applied Biosystems) according to manufacturer's recommended volumes. Controls were prepared using a 1:1 mix of DNA extracted from HEL TET2 monoallelic and HEL TET2 biallelic cells. Thermal cycling $\left(50^{\circ} \mathrm{C} 2 \mathrm{~min}, 95^{\circ} \mathrm{C} 10 \mathrm{~min}\right.$, followed by 40 cycles of $95^{\circ} \mathrm{C} 15 \mathrm{sec}, 60^{\circ} \mathrm{C} 1 \mathrm{~min}$ ) was performed using a 7300 Real Time PCR System (Applied Biosystems). Detected fluorescence for the two probes was converted to $\mathrm{Ct}$ values using SDS v1.4 software (Applied Biosystems) and a sample was considered positive if Ct was 38 or higher for either allele. In samples where only one allele was amplified in all replicates (due to complete domination of one cell population in the sample), a $\mathrm{Ct}$ of 38 was assigned to the non-amplified allele such that the sample could be included in the analysis. For all samples, adjusted $\triangle \mathrm{Ct}$ values (difference between WT TET2 allele $\mathrm{Ct}$ and $4 \mathrm{bp}$ deleted TET2 allele $\mathrm{Ct}$, adjusted by subtracting $\Delta \mathrm{Ct}$ calculated from the control DNA with 1:1 allelic ratio) were converted to inverse $\log _{2}$ values, such that a value of 1 indicated a 1:1 ratio between the two alleles (and hence the two cell populations in the sample). Inverse $\log _{2}[\Delta \mathrm{Ct}]$ values were compared between 5'-Aza-treated and VC-treated mice for each tissue type using the MannWhitney test.

Detailed methods for BM morphological assessment, cytogenetic analyses, nucleic acid preparation, SNP array genotyping, whole exome sequencing, RNA sequencing and differential gene expression analysis, methylation array and differential methylation analysis, mutation analysis (TET2, NPM1 and FLT3), western immunoblotting, cell proliferation, drug sensitivity and cloning efficiency assays are provided in supplemental Methods.

\section{Data sharing statement}


medRxiv preprint doi: https://doi.org/10.1101/2021.07.14.21259597; this version posted July 18, 2021. The copyright holder for this preprint (which was not certified by peer review) is the author/funder, who has granted medRxiv a license to display the preprint in perpetuity.

It is made available under a CC-BY 4.0 International license.

For all raw data, please contact james.allan@newcastle.ac.uk.

\section{Results}

\section{AML index case with biallelic TET2 mutation}

We describe a male who presented with AML characterized by a $\mathrm{t}(4 ; 12)$ translocation $(46, X Y, t(4 ; 12)(q 2 ? ; q 13)[12] / 46, X Y[10])$ (Figure 1A) which was resistant to remission induction chemotherapy with daunorubicin and cytarabine (Ara-C) (Figure 1B-C). Moreover, the patient became pancytopenic and developed acute septicemia requiring intensive care. Following recovery, the patient was treated with single agent 5' -azacitidine (5'-Aza) monthly as palliation (Figure 1B), which unexpectedly resulted in complete morphological remission (CR) (Figure 1C). The patient remained in CR for 24 months prior to emergence of relapsed AML which was unresponsive to chemotherapy and the patient died 28 months after first diagnosis. Autopsy revealed subtotal AML BM infiltration and multiple extramedullary AML sites (Figure S1). Single nucleotide polymorphism (SNP) array and FISH analysis of BM at AML presentation demonstrated that the major cell clone had a focal $1.1 \mathrm{Mb}$ deletion encompassing the TET2, CXXC4 and PPA2 genes (Figure 1D-E). Additionally, the retained TET2 allele harbored a nonsense base substitution mutation in exon 3 (c.2815C>T, Q939*; Figure S2) which was detected in $96 \%$ of cells. The presentation AML was also characterized by a heterozygous NPM1 mutation (c.863_864insTCTG; Figure S3). Construction of the tumor phylogeny indicated that disease pathogenesis was initiated by the TET2 nonsense mutation with subsequent deletion of the second TET2 allele, followed by acquisition of the NPM1 mutation (Figure 1F). Both the TET2 gene deletion and base substitution mutation were also present at high levels in the 
medRxiv preprint doi: https://doi.org/10.1101/2021.07.14.21259597; this version posted July 18, 2021. The copyright holder for this preprint (which was not certified by peer review) is the author/funder, who has granted medRxiv a license to display the preprint in perpetuity.

It is made available under a CC-BY 4.0 International license.

remission BM, despite this appearing morphologically normal (Figure 1C,F and Figure S2). The NPM1 mutation was presumed to have persisted at below detection levels during remission given that it was a prominent feature of relapse disease (Figure 1F and Figure S2-3). The relapse was also characterized by a heterozygous FLT3 internal tandem duplication (c.1780_1800dupTTCAGAGAATATGAATATGAT; Figure S4) which was not discernible in diagnostic or remission samples (Figure 1F and Figure S4).

These data demonstrate that 5'-Aza treatment almost completely eliminated the TET2/NPM1mutated clone dominant at disease presentation. Although also reduced by 5'-Aza treatment, ancestral AML cells carrying biallelic TET2 mutation, but negative for the NPM1 mutation, retained viability and presumably re-acquired the ability to differentiate and recapitulate normal hematopoiesis rendering CM. Based on these observations, we hypothesized that mutant TET2 allele dosage could affect cellular response and sensitivity to 5'-Aza.

Biallelic TET2 mutation result in a hypermethylation phenotype in AML cells and confer sensitivity to 5'-Aza hypomethylating chemotherapy in vitro and in vivo

In order to test whether biallelic TET2 mutation sensitize AML cells to 5'-Aza we used CRISPRCas9 gene editing to completely inactivate TET2 in the HEL AML cell line, which harbours a complex hypotriploid karyotype and a monoallelic TET2 gene deletion (Figure 2A; Table S1) ${ }^{8}$. CRISPR-Cas9 was used to generate independent cell clones with deletions in TET2 exon 6 (Figure S5) and null for TET2 protein expression (Figure 2B). Biallelic TET2 mutation did not affect proliferation in liquid media (Figure 2C) nor cloning efficiency (CE) (Figure 2D).

Analysis on human methylation (450K) arrays revealed the acquisition of an overall hypermethylation phenotype in TET2 biallelic clones compared to TET2 monoallelic clones 
medRxiv preprint doi: https://doi.org/10.1101/2021.07.14.21259597; this version posted July 18, 2021. The copyright holder for this preprint (which was not certified by peer review) is the author/funder, who has granted medRxiv a license to display the preprint in perpetuity.

It is made available under a CC-BY 4.0 International license .

(Figure 2E; Table S2). Unsupervised hierarchical clustering demonstrated clustering of HEL clones based on TET2 mutation status (Figure 2F).

When treated with 5'-Aza in vitro, HEL TET2 biallelic clones had significantly lower CE $(P=0.003)$ and proliferation in liquid culture $(P<0.001)$ compared to isogenic TET2 monoallelic clones (Figure 3A-B). In contrast, biallelic TET2 mutation did not affect CE or cell proliferation following treatment with Ara-C or daunorubicin (Figure 3A-B). Having demonstrated that HEL cells null for TET2 protein expression were sensitive to 5'-Aza we hypothesized that TET2 protein levels could affect sensitivity to 5'-Aza. In order to test this, we quantified TET2 protein levels in a panel of 10 AML cells lines and determined sensitivity to 5'-Aza (Figure 3C). There was significant correlation between TET2 protein levels and 5' -Aza IC90 $\left(\mathrm{R}^{2}=0.77, P=0.0008\right)$ and IC50 $\left(\mathrm{R}^{2}=0.88, P<0.0001\right)$ (Figure $\left.3 \mathrm{C}\right)$. THP1 cells had the highest TET2 protein expression and were the most resistant to 5'-Aza. In contrast, SKM1 cells had the lowest TET2 protein expression and were the most sensitive to 5'-Aza. Intriguingly, SKM1 cells have a monoallelic TET2 mutation (c.4253_4254insTT, p.1419fsX30) ${ }^{9}$ but are phenotypically null for TET2 protein expression despite having an intact WT TET2 allele (Figure 3C). As such, unlike biallelic TET2 deletion which renders cells null for TET2 expression, monoallelic TET2 mutation is not necessarily a good indicator of TET2 protein expression.

We next determined whether biallelic TET2 mutation sensitizes AML cells to 5' -Aza in vivo in an orthotopic xenograft mouse model. We used a competitive engraftment approach and an allele-specific qPCR assay for the WT and CRISPR-Cas9-modified TET2 alleles to determine preferential engraftment and/or elimination of either cell clone. Specifically, following prior validation of the qPCR assay (Figure S6), HEL TET2 monoallelic and HEL TET2 biallelic cell clones were co-injected intrafemorally (IF) in a $1: 1$ ratio into $\mathrm{Rag}^{-/-} \mathrm{Il2} \mathrm{rg}^{-/-}$mice (day 0; Figure 
medRxiv preprint doi: https://doi.org/10.1101/2021.07.14.21259597; this version posted July 18, 2021. The copyright holder for this preprint (which was not certified by peer review) is the author/funder, who has granted medRxiv a license to display the preprint in perpetuity.

It is made available under a CC-BY 4.0 International license .

4A). Physical symptoms associated with the proliferation of AML cells became apparent approximately 4 weeks post-IF injection. On day 28 mice began once daily treatment with $5 \mathrm{mg} / \mathrm{kg} 5$ '-Aza (or vehicle control (VC)) for a total of 5 days, and were then euthanized 3 days later for sample collection and qPCR analysis (Figure 4A). Human TET2 DNA consistently amplified using DNA from injected femurs, as well as non-injected femurs, spleens and other organs showing evidence of AML infiltration (32 individual samples from VC-treated mice and 23 from 5'-Aza-treated mice). There was no overall mean preferential amplification of either the intact WT or CRISPR-modified TET2 allele in all 32 tissue samples from VC-treated mice (Figure 4B), although the CRISPR-modified TET2 allele slightly dominated in spleen samples $(P=0.047$; Figure S7) suggesting preferential engraftment of TET2 null cells specifically in this tissue. Conversely, in 5'-Aza-treated mice the WT TET2 allele was dominant in 19 of 23 (83\%) tissue samples (Figure 4B), demonstrating significant negative selection against TET2 null cells $(P=0.0004)$ as a result of 5 ' -Aza treatment. There was also significant negative selection of TET2 null cells specifically in the BM of 5'-Aza-treated mice $(P=0.014)$ with 2 femur samples completely negative for the CRISPR-modified TET2 allele following 5'-Aza treatment (Figure 4B).

\section{Gene expression analysis identifies downregulation of small nuclear ribonucleoprotein}

\section{complex components in cells with biallelic TET2 mutation}

RNA sequencing analysis was performed to identify differentially expressed genes and potential mechanisms responsible for 5'-Aza sensitivity in HEL TET2 biallelic cell clones. HEL cell clones clustered broadly by TET2 genotype (Figure 5A), suggesting that complete loss of TET2 protein significantly impacted on transcription. Differential expression analysis identified 695 significantly differentially expressed transcripts $\left(\right.$ Padj<0.05; $\left.\left|\log _{2} \mathrm{FC}\right| \geq 0.3\right)$ in HEL TET2 
medRxiv preprint doi: https://doi.org/10.1101/2021.07.14.21259597; this version posted July 18, 2021. The copyright holder for this preprint (which was not certified by peer review) is the author/funder, who has granted medRxiv a license to display the preprint in perpetuity.

It is made available under a CC-BY 4.0 International license .

biallelic clones compared to HEL TET2 monoallelic clones (Figure 5B; Table S3) and gene ontology analysis identified several significantly affected cellular components (Table S4), of which the spliceosomal small nuclear ribonucleoprotein (snRNP) complex (GO:0097525) was the most significantly affected $\left(P a d j=8.7 \times 10^{-4}\right)($ Figure 5C; Table S5). Likewise, spliceosomal tri-snRNP complex assembly (GO:0000244) was identified as the most significantly affected biological process $\left(P a d j=3.4 \times 10^{-4}\right.$; Table S6). Downregulation of protein expression in TET2 null cells was confirmed for LSM8, consistent with transcript expression data (Figure 5D). Significant differences in expression were also identified for other genes that could potentially affect cellular response to $5^{\prime}$-Aza (Table S3). These included $A B C B 1(M D R 1)^{10}$, encoding a member of the ATP-binding cassette (ABC) family of drug transporters, which was downregulated in TET2 null cells at the transcript $\left(P a d j=8.1 \times 10^{-4}\right)$ and protein level (Figure 5D).

\section{Biallelic TET2 alterations in AML patients with cytogenetically discernible chromosome 4}

\section{aberrations}

The TET2 locus can be somatically affected via numerous mechanisms, although how these manifest to give rise to biallelic mutation remains unclear. In order to investigate this we screened the SAL biobank for AML patients presenting with a cytogenetically discernible aberration affecting chromosome 4; a population likely to be enriched for TET2 alterations. Ninety-two (6\%) of 1560 recruited AML cases had a chromosome 4 aberration visible cytogenetically, and sufficient material for our analyses was available for 30 cases (Table S7). Gains affecting TET2 were discernible by SNP array in 6 patients (all with trisomy 4 visible cytogenetically), which included two cases with homozygosity affecting most of the long arm of chromosome 4 (Figure 6A). One of these two patients (UPN25) also had a TET2 base substitution (c.4133G>A, p.Cys1378Tyr) carried by almost $100 \%$ of the cells (Figure 6A and 
medRxiv preprint doi: https://doi.org/10.1101/2021.07.14.21259597; this version posted July 18, 2021. The copyright holder for this preprint (which was not certified by peer review) is the author/funder, who has granted medRxiv a license to display the preprint in perpetuity.

It is made available under a CC-BY 4.0 International license.

Figure S8) and therefore has biallelic TET2 mutation. Six cases had loss of genetic material affecting TET2 discernible from SNP array data, which included three cases (UPN09, UPN10 and UPN18) with large deletions and two cases (index case (UPN01) and UPN30) with a focal deletion in one allele and a nonsense mutation in the other allele (Figure 6A and Figure S8). The sixth case (UPN28) had trisomy 4 but with a focal $585 \mathrm{~Kb}$ deletion affecting the entire TET2 gene, resulting in copy number reduction ( $<2$ copies) and loss of heterozygosity (Figure 6A and Figure S8). A further 6 cases had copy number alterations (5 with loss, 1 with gain) on chromosome 4 which did not affect the TET2 locus (Figure 6A). The remaining 12 cases had no evidence of TET2 base substitution or gain/loss of material on chromosome 4. In summary, in a panel of 30 AML cases with a cytogenetically discernible chromosome 4 abnormality, 7 patients (23\%) had loss of function TET2 mutation, including 4 (13\%) with monoallelic TET2 mutation (all of which were whole gene deletions reducing TET2 copy number) and 3 patients (10\%) with biallelic TET2 mutation (whole gene deletion plus nonsense mutation in two cases, and biallelic base substitutions resulting from a whole chromosome gain and loss of heterozygosity in the third case). These data demonstrate that TET2 alterations are complex, involving gains or losses of material in combination with base substitution mutations.

\section{Biallelic TET2 alterations in AML patients treated with 5-Aza}

Having described a single patient with biallelic TET2 mutation (UPN01) who responded very well to 5-Aza we sought to determine whether biallelic TET2 mutation affected response in other patients treated with 5-Aza. AML patients over the age of 65 years were recruited to the PETHEMA FLUGAZA phase 3 clinical trial and were randomized to receive either 5-Aza or low-dose Ara-C plus fludarabine (FLUGA) ${ }^{6}$. Fifty patients had a TET2 mutation identified by targeted sequencing which included 6 patients with a mutant allele frequency $>85 \%$ indicative of 
medRxiv preprint doi: https://doi.org/10.1101/2021.07.14.21259597; this version posted July 18, 2021. The copyright holder for this preprint (which was not certified by peer review) is the author/funder, who has granted medRxiv a license to display the preprint in perpetuity.

It is made available under a CC-BY 4.0 International license.

biallelic TET2 mutation (Table S8). None of the three patients with biallelic TET2 mutation randomized to the FLUGA arm (UPN68, UPN73, UPN78) achieved CR and all had relatively short OS (111, 45 and 17 days) (Figure 6B; Table S8). In contrast, 2 of the 3 patients with biallelic TET2 mutation randomized to the 5-Aza arm achieved CR (UPN31 and UPN33) and had prolonged OS (767 and 579 days) (Figure 6B; Table S8). The third patient treated with 5Aza (UPN47) failed to achieve CR and died (day 62) after cycle 1 with progressive disease (Figure 6B; Table S8). All three patients with biallelic TET2 mutation treated with 5-Aza had European LeukemiaNet (ELN) adverse risk AML and an Eastern Cooperative Oncology Group (ECOG) performance score of 3.

\section{Discussion}

Up to $30 \%$ of AML patients present with a somatically acquired TET2 mutation ${ }^{11-17}$, although those with biallelic mutation represent a small minority of all TET2-mutated AML cases ${ }^{17-19}$. The prognostic effect of TET2 mutation in AML treated with anthracycline and nucleoside analoguebased regimens remains controversial ${ }^{13,15,16}$, although meta-analyses suggest an association with poor prognosis ${ }^{20,21}$. As such, there is an urgent clinical need to identify novel therapeutic approaches to improve outcome of TET2-mutated AML. Some studies have reported an association between TET2 mutation and favorable outcome of myelodysplastic syndrome (MDS) following treatment with hypomethylating chemotherapy such as $5^{\prime}-\mathrm{Aza}^{22-26}$, although other studies have not replicated these findings ${ }^{27}$. Our data demonstrate that single-agent 5 '-Aza treatment of AML harboring biallelic TET2 mutation can give rise to long term CR, including in patients with disease refractory to standard remission induction chemotherapy and with adverse risk disease or poor performance status. Furthermore, using isogenic model systems, we demonstrate that biallelic TET2 mutation confers cellular hypersensitivity to 5' -Aza in vitro, as 
medRxiv preprint doi: https://doi.org/10.1101/2021.07.14.21259597; this version posted July 18, 2021. The copyright holder for this preprint (which was not certified by peer review) is the author/funder, who has granted medRxiv a license to display the preprint in perpetuity.

It is made available under a CC-BY 4.0 International license .

well as significant negative selection when competitively xenografted with monoallelic TET2mutated cells into BM of mice.

An effect of mutant TET2 gene dosage on response to therapy is perhaps not surprising given the evidence demonstrating that mutant allele dose also affects disease development. Monoallelic $\left(\right.$ Tet $\left.^{+/-}\right)$and biallelic Tet2 deletions $\left(\right.$Tet $\left.^{-/-}\right)$both result in myeloid malignancy in animal models, but the latency and OS are significantly shorter in Tet2 null animals ${ }^{28,29}$. Furthermore, Tet2 null $\left(\right.$ Tet $\left.^{-/-}\right)$mice with myeloid disease also have more pronounced splenomegaly compared to heterozygous $\left(\operatorname{Tet}^{+/-}\right)$littermates ${ }^{28}$, and splenomegaly (and extramedullary disease) is a general feature of myeloid disease developing in Tet 2 knockout mouse models ${ }^{29,30}$. Consistent with this, young healthy mice null for Tet 2 have elevated extramedullary hematopoiesis in the spleen, which develops into splenomegaly concomitant with the onset of myeloid dysplasia ${ }^{31}$. These observations are consistent with our data demonstrating a significant competitive advantage of TET2 null human cells to populate the spleen of engrafted animals and also splenomegaly and extramedullary disease in the index patient (UPN01) reported herein. Taken together, these data suggest that TET2 loss could predispose to myeloid disease characterized by splenomegaly and extramedullary disease in general, which is mutant TET2 gene dosage-dependent, although investigation in large patient cohorts is warranted.

Despite the observed negative selection against cells with biallelic TET2 mutation in vivo, 5-Aza treatment rarely resulted in the complete elimination of TET2 null cells, consistent with data from the index patient in whom 5'-Aza-induced morphological remission was characterized by the persistence of cells with biallelic TET2 mutation. Mutation persistence in morphological remission has been reported for several leukemia driver genes, including those characteristic of age-associated clonal hematopoiesis such as TET2, DNMT3A, SRSF2, RUNX1 and ASXL1 ${ }^{32-35}$. 
medRxiv preprint doi: https://doi.org/10.1101/2021.07.14.21259597; this version posted July 18, 2021. The copyright holder for this preprint (which was not certified by peer review) is the author/funder, who has granted medRxiv a license to display the preprint in perpetuity.

It is made available under a CC-BY 4.0 International license .

Likewise, persistence of Tet2-mutated cells has also been reported in animal models treated with ${ }^{5}$-Aza ${ }^{36}$. Our data demonstrate that cells with monoallelic and biallelic TET2 mutation have significantly different genomic methylation profiles, and although we observed a genome-wide shift towards hypermethylation in cells with biallelic TET2 mutation, the effect was relatively modest and there were also large numbers of $\mathrm{CpG}$ sites that became hypomethylated. Consistent with this, we also noted up-regulated transcript levels for numerous genes. As such, it seems unlikely that global genomic DNA methylation and concomitant global loss of expression is responsible for the observed sensitivity to 5'-Aza. Consistent with this model, pre-treatment DNA methylation levels do not correlate with clinical response in MDS to decitabine, the deoxynucleotide analogue of $5^{\prime}$-Aza ${ }^{37}$. Rather, the prevailing evidence suggests that the underlying mechanism conferring sensitivity to 5'-Aza is gene/pathway specific, and our investigations identified significant down-regulation of spliceosomal small nuclear ribonucleoprotein (snRNP) complex components in cells with biallelic TET2 mutation. The snRNP pathway has previously been implicated as a determinant of cellular sensitivity to 5'$\mathrm{Aza}^{38}$, although the underlying mechanisms remain to be fully deciphered.

Mutations in other genes operating in the TET2 hydroxymethylation pathway are also reported in AML, including IDH1, IDH2 and WT1. Mutations in IDH1 and IDH2 inhibit TET2 function (and TET1 and TET3) via production of 2-hydroxyglutarate ${ }^{39}$, but are always heterozygous in $\mathrm{AML}^{40,41}$, suggesting a strong oncogenic gain of function phenotype where monoallelic mutation is sufficient to drive transformation with no selective pressure for loss of the second WT IDHI or IDH2 allele. In contrast, both monoallelic and biallelic WT1 mutations are reported in $\mathrm{AML}^{42}$ and drive leukemogenesis via inhibition of TET2 specifically. As such, loss of WT1 phenocopies loss of TET2 function and gives rise to a similar hypermethylation signature and a similar 
medRxiv preprint doi: https://doi.org/10.1101/2021.07.14.21259597; this version posted July 18, 2021. The copyright holder for this preprint (which was not certified by peer review) is the author/funder, who has granted medRxiv a license to display the preprint in perpetuity.

It is made available under a CC-BY 4.0 International license .

hematopoietic differentiation phenotype ${ }^{43}$. It will therefore be important to determine whether mutations in WT1, and particularly biallelic mutation, confers sensitivity to 5'-Aza. TET2 mutations have also been reported in up to $28 \%$ of MDS and $\mathrm{MPN}^{12,17,44}$ and up to $50 \%$ of angioimmunoblastic T-cell lymphoma (AITL), where they are associated with poor response to anthracycline-based chemotherapy ${ }^{45}$. However, there is evidence of sensitivity to 5 '-Aza in TET2-mutated AITL cases ${ }^{46}$, with prolonged CR reported in one case with double (presumed biallelic) mutation ${ }^{45}$.

Models for reliably predicting response to 5'-Aza in AML would be of clinical benefit. Our study suggests that TET2 mutational profiling or TET2 protein expression analysis could potentially identify a subgroup of patients acutely sensitive to hypomethylating therapy, suggesting an alternative first line therapy for frail AML patients or salvage therapy for patients with chemoresistant disease. There is potential value in advocating TET2 mutational or protein expression profiling in elderly patients with AML, where disease is more likely to have evolved from TET2 clonal hematopoiesis and therefore likely to be enriched for AML with biallelic TET2 mutation and null for expression ${ }^{17}$. Indeed, clinical studies in elderly AML have already documented excellent responses to $5^{\prime}$-Aza in some patients ${ }^{47}$, although the impact of TET2 status would need to be confirmed in prospective studies in all age groups. Likewise, there is a case to be made for implementing TET2 mutational or expression profiling in AML patients with extramedullary disease, and particularly splenomegaly, given our data linking biallelic TET2 mutation with colonization of the spleen in conjunction with data from mouse models showing a proclivity of Tet2 mutation to drive extramedullary hematopoiesis and myeloid disease.

In summary, the prevailing evidence argues in favor of investigating mutant TET2 allele dosage and TET2 protein expression as a determinant of sensitivity to $5^{\prime}$-Aza in large prospective 
studies of AML and other hematological conditions characterized by TET2 loss of function. However, comprehensive TET2 mutational profiling that includes both sequence and copy number analysis would be required to identify patients with potentially complex alterations affecting the TET2 locus. Furthermore, TET2 expression profiling could identify patients with disease that is null/low for protein expression despite the presence of at least one WT TET2 allele, and who might also benefit from 5'-Aza treatment. 
medRxiv preprint doi: https://doi.org/10.1101/2021.07.14.21259597; this version posted July 18, 2021. The copyright holder for this preprint (which was not certified by peer review) is the author/funder, who has granted medRxiv a license to display the preprint in perpetuity.

It is made available under a CC-BY 4.0 International license.

\section{Acknowledgments}

The authors wish to acknowledge Professor J. Kotzerke for providing PET-CT images (Figure.

S1). This work was funded by a specialist programme grant from Blood Cancer UK (\#13044 to

JMA). This work was also supported in part by a grant from the German Consortium for

Translational Cancer Research (DKTK) Dresden (to FS), the J.G.W. Patterson Foundation

(\#30015.088.085/PA/IXS to JMA) and the Accelerator award CRUK/AIRC/AECC joint funder partnership.

\section{Authorship}

Contribution: FS, SEF and W-YL designed experiments, generated data, analyzed data and wrote the manuscript. HB, CE, BM, LR, DK, CD, DA, DN, RP, E-NS, CP, MF, TR, AA, MW, HA, CR, LW, GLJ, TM, GHJ, HJM, JF, KO, MM, OH, TH, SV, BA, RAD, FP, PM, JM-L and MB generated/collated data and/or advised on data analysis. JMA designed experiments, generated data, analyzed data, directed the research and wrote the manuscript. FS and JMA also conceived of the project and secured funding. All authors contributed to the final version of the manuscript.

Conflict-of-interest disclosures: MM is employed by the Munich Leukemia Laboratory and TH is part owner of the Munich Leukemia Laboratory. The remaining authors declare no competing financial interests or conflicts of interest.

Correspondence: James M Allan, Newcastle Centre for Cancer, Newcastle University, Newcastle Upon Tyne, UK; e-mail: james.allan@ newcastle.ac.uk; phone: +44 (0)191 208 4435; fax: +44

(0)191 208 4301. Friedrich Stölzel, Medizinische Klinik und Poliklinik I, Universitätsklinikum Dresden, TU Dresden, Dresden, Germany; e-mail: friedrich.stoelzel@ uniklinikum-dresden.de 
medRxiv preprint doi: https://doi.org/10.1101/2021.07.14.21259597; this version posted July 18, 2021. The copyright holder for this preprint

(which was not certified by peer review) is the author/funder, who has granted medRxiv a license to display the preprint in perpetuity.

It is made available under a CC-BY 4.0 International license .

\section{References}

1. Papaemmanuil E, Gerstung M, Bullinger L, et al. Genomic Classification and Prognosis in Acute Myeloid Leukemia. N Engl J Med. 2016;374(23):2209-2221.

2. Stone RM, Mandrekar SJ, Sanford BL, et al. Midostaurin plus Chemotherapy for Acute Myeloid Leukemia with a FLT3 Mutation. N Engl J Med. 2017;377(5):454-464.

3. Roman E, Smith A, Appleton S, et al. Myeloid malignancies in the real-world: Occurrence, progression and survival in the UK's population-based Haematological Malignancy Research Network 2004-15. Cancer Epidemiol. 2016;42:186-198.

4. Patel JP, Gonen M, Figueroa ME, et al. Prognostic relevance of integrated genetic profiling in acute myeloid leukemia. N Engl J Med. 2012;366(12):1079-1089.

5. Prensner JR, Chinnaiyan AM. Metabolism unhinged: IDH mutations in cancer. Nat Med. 2011;17(3):291-293.

6. Vives S, Martinez-Cuadron D, Bergua Burgues J, et al. A phase 3 trial of azacitidine versus a semi-intensive fludarabine and cytarabine schedule in older patients with untreated acute myeloid leukemia. Cancer. 2021.

7. Traggiai E, Chicha L, Mazzucchelli L, et al. Development of a human adaptive immune system in cord blood cell-transplanted mice. Science. 2004;304(5667):104-107.

8. Abdel-Wahab O, Mullally A, Hedvat C, et al. Genetic characterization of TET1, TET2, and TET3 alterations in myeloid malignancies. Blood. 2009;114(1):144-147.

9. Cluzeau T, Dubois A, Jacquel A, et al. Phenotypic and genotypic characterization of azacitidine-sensitive and resistant SKM1 myeloid cell lines. Oncotarget. 2014;5(12):43844391.

10. Lainey E, Wolfromm A, Marie N, et al. Azacytidine and erlotinib exert synergistic effects against acute myeloid leukemia. Oncogene. 2013;32(37):4331-4342.

11. Damm F, Markus B, Thol F, et al. TET2 mutations in cytogenetically normal acute myeloid leukemia: clinical implications and evolutionary patterns. Genes Chromosomes Cancer. 2014;53(10):824-832.

12. Delhommeau F, Dupont S, Della Valle V, et al. Mutation in TET2 in myeloid cancers. $N$ Engl J Med. 2009;360(22):2289-2301.

13. Gaidzik VI, Paschka P, Spath D, et al. TET2 mutations in acute myeloid leukemia (AML): results from a comprehensive genetic and clinical analysis of the AML study group. J Clin Oncol. 2012;30(12):1350-1357.

14. Metzeler KH, Maharry K, Radmacher MD, et al. TET2 mutations improve the new European LeukemiaNet risk classification of acute myeloid leukemia: a Cancer and Leukemia Group B study. J Clin Oncol. 2011;29(10):1373-1381.

15. Nibourel $\mathrm{O}$, Kosmider $\mathrm{O}$, Cheok $\mathrm{M}$, et al. Incidence and prognostic value of TET2 alterations in de novo acute myeloid leukemia achieving complete remission. Blood. 2010;116(7):1132-1135.

16. Shen Y, Zhu YM, Fan X, et al. Gene mutation patterns and their prognostic impact in a cohort of 1185 patients with acute myeloid leukemia. Blood. 2011;118(20):5593-5603.

17. Hirsch CM, Nazha A, Kneen K, et al. Consequences of mutant TET2 on clonality and subclonal hierarchy. Leukemia. 2018;32(8):1751-1761.

18. Ahn JS, Kim HJ, Kim YK, et al. Adverse prognostic effect of homozygous TET2 mutation on the relapse risk of acute myeloid leukemia in patients of normal karyotype.

Haematologica. 2015;100(9):e351-353. 
medRxiv preprint doi: https://doi.org/10.1101/2021.07.14.21259597; this version posted July 18, 2021. The copyright holder for this preprint

(which was not certified by peer review) is the author/funder, who has granted medRxiv a license to display the preprint in perpetuity.

It is made available under a CC-BY 4.0 International license .

19. Awada H, Nagata Y, Goyal A, et al. Invariant phenotype and molecular association of biallelic TET2 mutant myeloid neoplasia. Blood Adv. 2019;3(3):339-349.

20. Liu WJ, Tan XH, Luo XP, et al. Prognostic significance of Tet methylcytosine dioxygenase 2 (TET2) gene mutations in adult patients with acute myeloid leukemia: a meta-analysis. Leuk Lymphoma. 2014;55(12):2691-2698.

21. Wang R, Gao X, Yu L. The prognostic impact of tet oncogene family member 2 mutations in patients with acute myeloid leukemia: a systematic-review and meta-analysis. $B M C$ Cancer. 2019;19(1):389.

22. Itzykson R, Kosmider O, Cluzeau T, et al. Impact of TET2 mutations on response rate to azacitidine in myelodysplastic syndromes and low blast count acute myeloid leukemias. Leukemia. 2011;25(7):1147-1152.

23. Bejar R, Lord A, Stevenson K, et al. TET2 mutations predict response to hypomethylating agents in myelodysplastic syndrome patients. Blood. 2014;124(17):2705-2712.

24. Cedena MT, Rapado I, Santos-Lozano A, et al. Mutations in the DNA methylation pathway and number of driver mutations predict response to azacitidine in myelodysplastic syndromes. Oncotarget. 2017;8(63):106948-106961.

25. Lin Y, Lin Z, Cheng K, et al. Prognostic role of TET2 deficiency in myelodysplastic syndromes: A meta-analysis. Oncotarget. 2017;8(26):43295-43305.

26. Patel BJ, Przychodzen B, Thota S, et al. Genomic determinants of chronic myelomonocytic leukemia. Leukemia. 2017;31(12):2815-2823.

27. Dohner H, Dolnik A, Tang L, et al. Cytogenetics and gene mutations influence survival in older patients with acute myeloid leukemia treated with azacitidine or conventional care. Leukemia. 2018;32(12):2546-2557.

28. Li Z, Cai X, Cai CL, et al. Deletion of Tet2 in mice leads to dysregulated hematopoietic stem cells and subsequent development of myeloid malignancies. Blood. 2011;118(17):4509-4518.

29. Shih AH, Jiang Y, Meydan C, et al. Mutational cooperativity linked to combinatorial epigenetic gain of function in acute myeloid leukemia. Cancer Cell. 2015;27(4):502-515.

30. Kunimoto H, Meydan C, Nazir A, et al. Cooperative Epigenetic Remodeling by TET2 Loss and NRAS Mutation Drives Myeloid Transformation and MEK Inhibitor Sensitivity. Cancer Cell. 2018;33(1):44-59 e48.

31. Moran-Crusio K, Reavie L, Shih A, et al. Tet2 loss leads to increased hematopoietic stem cell self-renewal and myeloid transformation. Cancer Cell. 2011;20(1):11-24.

32. Rothenberg-Thurley M, Amler S, Goerlich D, et al. Persistence of pre-leukemic clones during first remission and risk of relapse in acute myeloid leukemia. Leukemia. 2018.

33. Corces-Zimmerman MR, Hong WJ, Weissman IL, Medeiros BC, Majeti R. Preleukemic mutations in human acute myeloid leukemia affect epigenetic regulators and persist in remission. Proc Natl Acad Sci U S A. 2014;111(7):2548-2553.

34. Klco JM, Miller CA, Griffith M, et al. Association Between Mutation Clearance After Induction Therapy and Outcomes in Acute Myeloid Leukemia. JAMA. 2015;314(8):811822.

35. Morita K, Kantarjian HM, Wang F, et al. Clearance of Somatic Mutations at Remission and the Risk of Relapse in Acute Myeloid Leukemia. J Clin Oncol. 2018;36(18):1788-1797.

36. Shih AH, Meydan C, Shank K, et al. Combination Targeted Therapy to Disrupt Aberrant Oncogenic Signaling and Reverse Epigenetic Dysfunction in IDH2- and TET2-Mutant Acute Myeloid Leukemia. Cancer Discov. 2017;7(5):494-505. 
medRxiv preprint doi: https://doi.org/10.1101/2021.07.14.21259597; this version posted July 18, 2021. The copyright holder for this preprint

(which was not certified by peer review) is the author/funder, who has granted medRxiv a license to display the preprint in perpetuity.

It is made available under a CC-BY 4.0 International license .

37. Shen L, Kantarjian H, Guo Y, et al. DNA methylation predicts survival and response to therapy in patients with myelodysplastic syndromes. J Clin Oncol. 2010;28(4):605-613.

38. Cheng JX, Chen L, Li Y, et al. RNA cytosine methylation and methyltransferases mediate chromatin organization and 5-azacytidine response and resistance in leukaemia. Nat Commun. 2018;9(1):1163.

39. Figueroa ME, Abdel-Wahab O, Lu C, et al. Leukemic IDH1 and IDH2 mutations result in a hypermethylation phenotype, disrupt TET2 function, and impair hematopoietic differentiation. Cancer Cell. 2010;18(6):553-567.

40. Medeiros BC, Fathi AT, DiNardo CD, Pollyea DA, Chan SM, Swords R. Isocitrate dehydrogenase mutations in myeloid malignancies. Leukemia. 2017;31(2):272-281.

41. Schnittger S, Haferlach C, Ulke M, Alpermann T, Kern W, Haferlach T. IDH1 mutations are detected in $6.6 \%$ of 1414 AML patients and are associated with intermediate risk karyotype and unfavorable prognosis in adults younger than 60 years and unmutated NPM1 status. Blood. 2010;116(25):5486-5496.

42. Hou HA, Huang TC, Lin LI, et al. WT1 mutation in 470 adult patients with acute myeloid leukemia: stability during disease evolution and implication of its incorporation into a survival scoring system. Blood. 2010;115(25):5222-5231.

43. Rampal R, Alkalin A, Madzo J, et al. DNA hydroxymethylation profiling reveals that WT1 mutations result in loss of TET2 function in acute myeloid leukemia. Cell Rep. 2014;9(5):1841-1855.

44. Langemeijer SM, Kuiper RP, Berends M, et al. Acquired mutations in TET2 are common in myelodysplastic syndromes. Nat Genet. 2009;41(7):838-842.

45. Saillard C, Guermouche H, Derrieux C, et al. Response to 5-azacytidine in a patient with TET2-mutated angioimmunoblastic T-cell lymphoma and chronic myelomonocytic leukaemia preceded by an EBV-positive large B-cell lymphoma. Hematol Oncol. 2017;35(4):864-868.

46. Cheminant M, Bruneau J, Kosmider O, et al. Efficacy of 5-azacytidine in a TET2 mutated angioimmunoblastic T cell lymphoma. Br J Haematol. 2015;168(6):913-916.

47. Pollyea DA, Zehnder J, Coutre S, et al. Sequential azacitidine plus lenalidomide combination for elderly patients with untreated acute myeloid leukemia. Haematologica. 2013;98(4):591-596. 
medRxiv preprint doi: https://doi.org/10.1101/2021.07.14.21259597; this version posted July 18, 2021. The copyright holder for this preprint

(which was not certified by peer review) is the author/funder, who has granted medRxiv a license to display the preprint in perpetuity.

It is made available under a CC-BY 4.0 International license .

\section{Figure Legends}

Figure 1. Biallelic TET2 mutation in a patient with 5'-Aza-sensitive AML. (a) Identification of the $\mathrm{t}(4 ; 12)$ translocation by G-banding (top) and spectral karyotyping (bottom) in leukemic blasts from the AML index patient (UPN01). Translocated chromosomes 4 and 12 are arrowed. (b) Hemoglobin, platelet and white blood cell (WBC) counts from diagnosis to relapse of UPN01. Grey shading indicates period of induction chemotherapy with daunorubicin and Ara-C (DA). Initiations of palliative 5'-Aza treatment cycles are arrowed. (c) Giemsa-stained BM smears at day 30 (left) (after failed induction chemotherapy) and day 180 (right) (during 5'-Azainduced remission) in UPN01. Images are 500x magnification. (d) High density array copy number profiles of chromosome 4 from leukemic blasts of UPN01 at AML presentation, during $\mathrm{CR}$ and at relapse. Points represent individual SNPs, aligned relative to their position on chromosome 4 (indicated by the ideogram). Copy number is measured as Log $\mathrm{R}$ ratio, with 0 indicating diploid SNPs and positive and negative values indicating gain and loss, respectively. $B$ allele frequency represents the ratio of the two alleles of each SNP such that 0.5 indicates allele heterozygosity and 0 and 1 indicate homozygosity. Inset shows expanded view of the boxed region. Green bar above plots highlights focal deletion within 4q24 encompassing TET2, CXCC4 and PPA2 (locations indicated by bars below plots). (e) FISH on leukemic blasts from UPN01 showing TET2 (red) deletion in a metaphase cell (left of image) and two interphase cells (right of image). A probe binding within 4q12 (green) was used as reference. (f) Fishplot derived from sequencing analysis of leukemic blasts from UPN01 showing temporal acquisition of a TET2 point mutation, TET2 deletion, a NPM1 insertion mutation and FLT3 internal tandem duplication (ITD). Dashed lines represent timepoints at which blasts were analyzed. PRES; disease presentation, CR; complete remission, REL; relapse.

Figure 2. Complete loss of TET2 expression confers a hypermethylation phenotype. (a) High density array copy number profile of chromosome 4 from HEL cells showing large deletion (green bar) affecting the $\mathrm{q}$ arm, including TET2 (position indicated by dashed red line). (b) Immunoblot showing TET2 protein expression in two representative parental TET2 monoallelic HEL cell clones (HEL TET2 monoallelic) and three representative TET2 CRISPR-Cas9-mutated HEL cell clones (HEL TET2 biallelic). $\alpha$-tubulin was used as loading control. (c) Growth kinetics in suspension culture of HEL TET2 monoallelic (open circles) and HEL TET2 biallelic (filled circles) cell clones. Cells were seeded at low density and growth (relative to initial density) was determined at regular intervals. Data represents mean and SD of indicated number of clones from three independent experiments. $P$ value calculated by one-way ANOVA. (d) CE was calculated for HEL TET2 monoallelic (open squares) and HEL TET2 biallelic (filled squares) clones after 30 days culture in soft agar. Mean and SD of indicated number of clones from seven independent experiments are shown. $P$ value calculated by 2 -tailed Student's t-test. (e) Volcano plot demonstrating differences in CpG methylation between HEL TET2 monoallelic $(\mathrm{n}=2)$ and HEL TET2 biallelic $(\mathrm{n}=4)$ clones. Plot was constructed using fold-change $\left(\log _{2} \mathrm{FC}\right)$ values and adjusted $P$-values and points represent individual $\mathrm{CpG}$ probes, colored such that significantly differentially methylated probes $\left(P<0.05\right.$ and $\left.\left|\log _{2} \mathrm{FC}\right| \geq 2\right)$ are in red. Orange points represent probes which reach significance $(P<0.05)$ but are not differentially methylated $\left(\left|\log _{2} \mathrm{FC}\right|<2\right)$ and black points represent non-significant $(P \geq 0.05)$ probes. (f) Unsupervised hierarchical clustering of the top 1,500 differentially methylated CpG probes across all samples resulted in distinct clustering of parental HEL TET2 monoallelic $(\mathrm{n}=2)$ and HEL TET2 biallelic 
medRxiv preprint doi: https://doi.org/10.1101/2021.07.14.21259597; this version posted July 18, 2021. The copyright holder for this preprint

(which was not certified by peer review) is the author/funder, who has granted medRxiv a license to display the preprint in perpetuity.

It is made available under a CC-BY 4.0 International license .

$(\mathrm{n}=4)$ cell clones. Rows in the heatmap represent $\mathrm{CpG}$ probes and vertical columns are cell clones. Color key indicates level of methylation at CpGs.

Figure 3. Cells with biallelic TET2 mutation are sensitive to the hypomethylating agent, 5'Aza in in vitro model systems. (a) Parental TET2 monoallelic HEL cell clones (HEL TET2 monoallelic; open squares) and TET2 CRISPR-Cas9-mutated HEL cell clones (HEL TET2 biallelic; filled squares) were cultured in soft agar supplemented with 1nM 5'-Aza (left), 20nM Ara-C (center) or 20nM daunorubicin (right) and CE (relative to respective vehicle controltreated cells) was determined after 30 days. Mean and SD of indicated number of clones from three independent experiments are shown. $P$ values calculated by Student's t-test (2-tailed). (b) Parental TET2 monoallelic HEL cell clones (HEL TET2 monoallelic; open circles) and TET2 CRISPR-Cas9-mutated HEL cell clones (HEL TET2 biallelic; filled circles) were treated with 5'Aza (left), Ara-C (center) or daunorubicin (right) and cell density (relative to respective vehicle control-treated cells) was determined after $96 \mathrm{hrs}$. Data represents mean and SD of indicated number of clones from three independent experiments. $P$ values calculated by two-way ANOVA. (c) Western blot (top panel) showing TET2 protein expression in a panel of 10 AML cell lines. GAPDH was used as a loading control. TET2 protein expression was quantified in each cell line and plotted against 5'-Aza IC50 (left) and IC90 (right) values. AU represents arbitrary units as measured by the Fuji LAS-300 Image Analyzer System.

Figure 4. Cells with biallelic TET2 mutation are subject to 5'-Aza-induced negative selection in an orthotopic AML mouse model. (a) Schematic of orthotopic AML mouse model. HEL TET2 monoallelic and HEL TET2 biallelic cell clones were co-injected in a 1:1 ratio into the femurs of $\mathrm{Rag}^{-/-} \mathrm{Il2} \mathrm{rg}^{-/-}$mice. Treatment with $5-\mathrm{Aza}(5 \mathrm{mg} / \mathrm{kg}$ daily for 5 days) or VC was initiated on day 28 (post-injection) and tissues were harvested on day 35 for TET2 allelespecific qPCR analysis. (b) Tissue samples collected from mice were analyzed by custom TET2 allele-specific qPCR assay. Shown are inverse $\log _{2}[\triangle \mathrm{Ct}]$ values which represent relative expression of the WT versus the 4bp deleted TET2 allele in individual samples, and are the means of triplicate reactions. Inverse $\log _{2}[\Delta \mathrm{Ct}]$ of 1 indicates a 1:1 ratio between the WT and $4 \mathrm{bp}$ deleted TET2 alleles (and hence HEL TET2 monoallelic and HEL TET2 biallelic clones), whereas inverse $\log _{2}[\Delta \mathrm{Ct}]>1$ or inverse $\log _{2}[\Delta \mathrm{Ct}]<1$ indicates dominance of the WT (HEL TET2 monoallelic) or 4bp deleted (HEL TET2 biallelic) allele, respectively. Red points indicate samples which were dominated entirely by one cell clone. Horizontal dashed lines represent median inverse $\log _{2}[\Delta \mathrm{Ct}]$ values across all samples from VC- or 5'-Aza-treated mice. The left panel shows data from all harvested tissues (BM, PB, spleen and tumors) and the right panel shows data from BM only. $P$ values comparing inverse $\log _{2}[\Delta \mathrm{Ct}]$ values from $\mathrm{VC}$ and 5' -Azatreated mice were calculated using a Mann-Whitney test.

Figure 5. Differential gene expression in AML cells with monoallelic and biallelic TET2 mutation. (a) Unsupervised hierarchical clustering of the top 1,500 differentially expressed transcripts in parental TET2 monoallelic HEL cell clones (HEL TET2 monoallelic; $\mathrm{n}=3$ ) and TET2 CRISPR-Cas9-mutated HEL cell clones (HEL TET2 biallelic; $n=3$ ). Horizontal rows of the heatmap represent individual transcripts and each vertical column is a cell clone. Color indicates relative expression with down-regulated and up-regulated transcripts indicated in blue and red, respectively. (b) Volcano plot demonstrating significant differential gene expression $(P$ value $<0.05$ and $\left|\log _{2} \mathrm{FC}\right| \geq 0.3$ ) in TET2 CRISPR-Cas9-mutated HEL cell clones (HEL TET2 biallelic; $\mathrm{n}=3$ ) relative to parental HEL clones with monoallelic TET2 mutation (HEL TET2 
medRxiv preprint doi: https://doi.org/10.1101/2021.07.14.21259597; this version posted July 18, 2021. The copyright holder for this preprint (which was not certified by peer review) is the author/funder, who has granted medRxiv a license to display the preprint in perpetuity.

It is made available under a CC-BY 4.0 International license.

monoallelic; $\mathrm{n}=3)$. Plot was constructed using fold-change $\left(\log _{2} \mathrm{FC}\right)$ values and adjusted $P$ values and points represent individual gene transcripts. Shown are 326 significantly downregulated transcripts (blue) and 369 significantly up-regulated transcripts (red). Non-significant (NS) transcripts $(P$-value $\geq 0.05)$ are represented by grey points. Genes with particularly significant differential expression are labelled. (c) Heatmap showing differential expression of components of the spliceosomal snRNP complex (GO:009752) in parental TET2 monoallelic HEL cell clones (HEL TET2 monoallelic; $n=3$ ) and TET2 CRISPR-Cas9-mutated HEL cell clones (HEL TET2 biallelic; $n=3$ ). Horizontal rows represent genes and each vertical column is a cell clone. Color indicates relative expression, as in (a). (d) Transcript expression (expressed as counts per million (CPM) reads) of LSM8 (top) and ABCB1 (bottom) in parental TET2 monoallelic HEL cell clones (HEL TET2 monoallelic; open bars) and TET2 CRISPR-Cas9mutated HEL cell clones (HEL TET2 biallelic; filled bars). Data represents the mean and SD of indicated number of clones. $P$ values are from differential expression analysis. Western blots to the right of the charts show corresponding protein expression in the individual cell clones included in RNA sequencing analysis. $\alpha$-tubulin was used as a loading control.

Figure 6. Somatic mutations affecting the TET2 locus in AML patients with cytogenetic abnormality of chromosome 4 and response to treatment in AML patients with TET2 mutation. (a) Illustrated are regions of copy number gain (green), gain with concomitant LOH (blue) and loss (orange) affecting chromosome 4 (discerned using high-density SNP array) in 18 AML patients with cytogenetically detectable abnormalities of chromosome 4 . Base substitution mutations (indicated by black triangles) were determined by TET2 exon sequencing. The vertical dashed red line indicates the location of the TET2 gene. The mutation status of the 7 patients with loss of function TET2 mutations are indicated to the right. Patient ID numbers are shown in parentheses for these patients. (b) Swimmer plots showing patients with TET2 mutated AML treated with either 5'-Aza (left) or low-dose Ara-C plus fludarabine (FLUGA) (right). The AML index case (UPN01) is included in the 5'-Aza swimmer plot for reference. Patients with biallelic TET2 mutation (UPN01, UPN31, UPN33, UPN47, UPN68, UPN73 and UPN78) are represented by purple bars. All other patients had monoallelic TET2 mutation discerned by whole exome sequencing and are represented by pale yellow bars. European LeukemiaNet (ELN) favorable, intermediate and adverse risk groups are represented by green, blue and red squares, respectively. ECOG, Eastern Cooperative Oncology Group performance score. 
medRxiv preprint doi: https://doi.org/10.1101/2021.07.14.21259597; this version posted July 18, 2021. The copyright holder for this preprint (which was not certified by peer review) is the author/funder, who has granted medRxiv a license to display the preprint in perpetuity. Figure 1 It is made available under a CC-BY 4.0 International license.
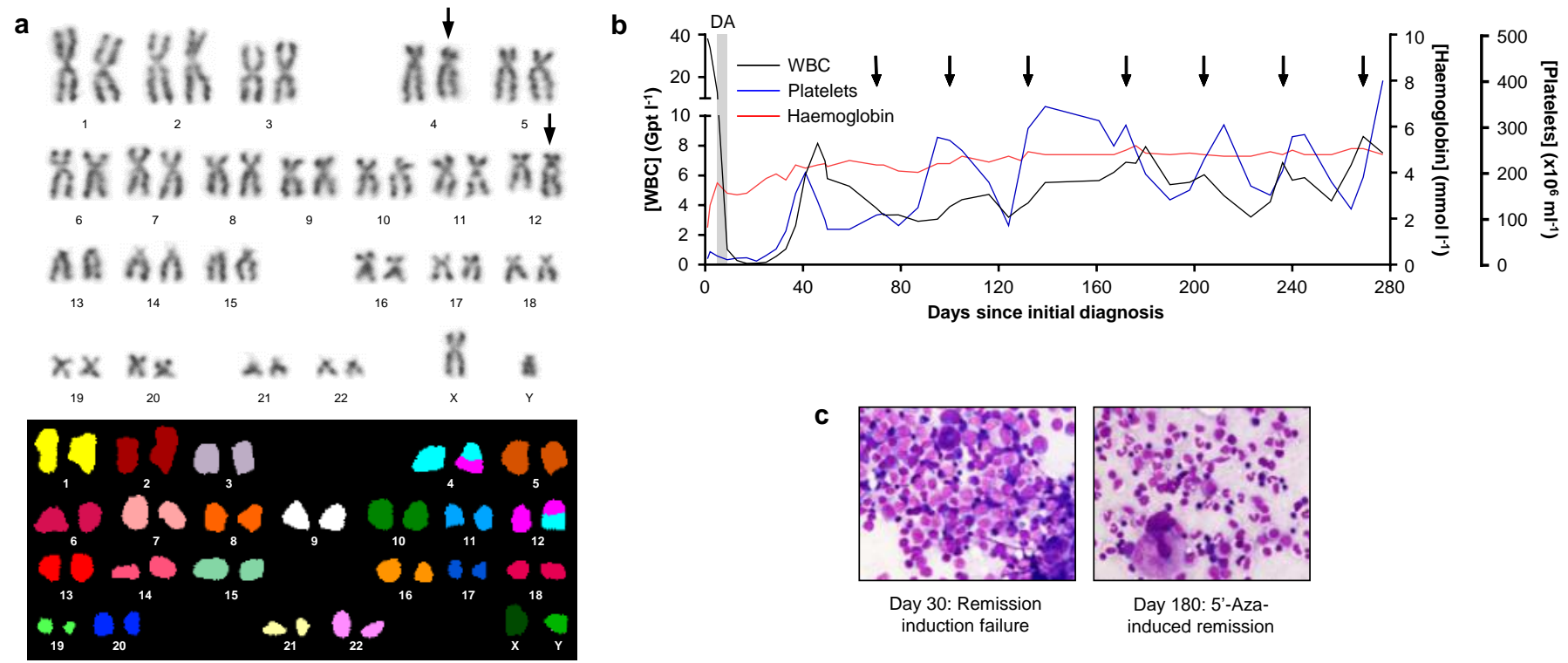

C
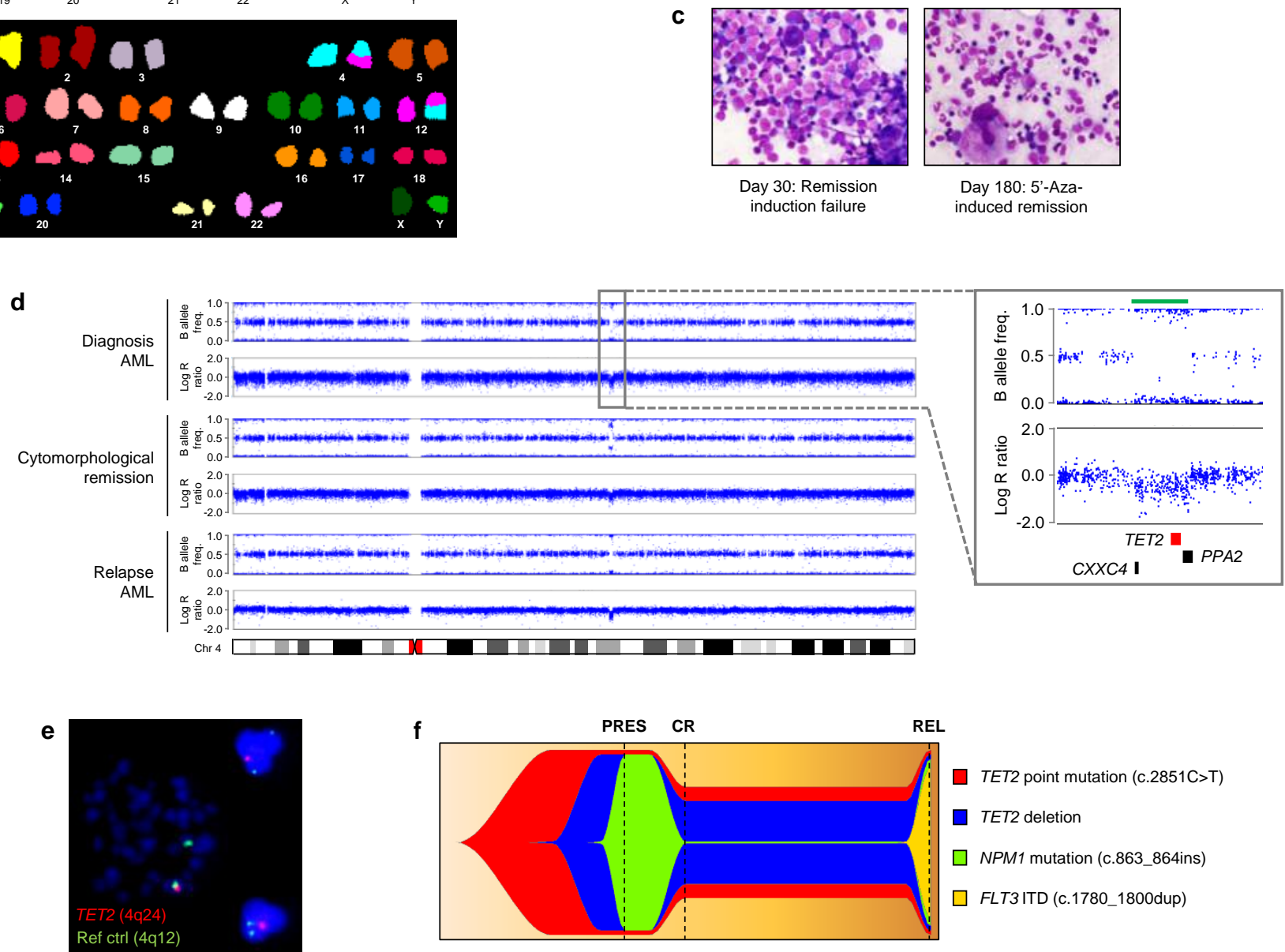

Figure 1. Biallelic TET2 mutation in a patient with 5'-Aza-sensitive AML.

(a) Identification of the $\mathrm{t}(4 ; 12)$ translocation by G-banding (top) and spectral karyotyping (bottom) in leukemic blasts from the AML index patient (UPN01). Translocated chromosomes 4 and 12 are arrowed. (b) Hemoglobin, platelet and white blood cell (WBC) counts from diagnosis to relapse of UPN01. Grey shading indicates period of induction chemotherapy with daunorubicin and Ara-C (DA). Initiations of palliative 5'-Aza treatment cycles are arrowed. (c) Giemsa-stained BM smears at day 30 (left) (after failed induction chemotherapy) and day 180 (right) (during 5'-Aza-induced remission) in UPN01. Images are 500x magnification. (d) High density array copy number profiles of chromosome 4 from leukemic blasts of UPN01 at AML presentation, during CR and at relapse. Points represent individual SNPs, aligned relative to their position on chromosome 4 (indicated by the ideogram). Copy number is measured as Log $\mathrm{R}$ ratio, with 0 indicating diploid SNPs and positive and negative values indicating gain and loss, respectively. B allele frequency represents the ratio of the two alleles of each SNP such that 0.5 indicates allele heterozygosity and 0 and 1 indicate homozygosity. Inset shows expanded view of the boxed region. Green bar above plots highlights focal deletion within 4q24 encompassing TET2, CXCC4 and PPA2 (locations indicated by bars below plots). (e) FISH on leukemic blasts from UPN01 showing TET2 (red) deletion in a metaphase cell (left of image) and two interphase cells (right of image). A probe binding within 4q12 (green) was used as reference. (f) Fishplot derived from sequencing analysis of leukemic blasts from UPN01 showing temporal acquisition of a TET2 point mutation, TET2 deletion, a NPM1 insertion mutation and FLT3 internal tandem duplication (ITD). Dashed lines represent timepoints at which blasts were analyzed. PRES; disease presentation, CR; complete remission, REL; relapse. 
medRxiv preprint doi: https://doi.org/10.1101/2021.07.14.21259597; this version posted July 18, 2021. The copyright holder for this preprint (which was not certified by peer review) is the author/funder, who has granted medRxiv a license to display the preprint in perpetuity. It is made available under a CC-BY 4.0 International license.

Figure 2

a

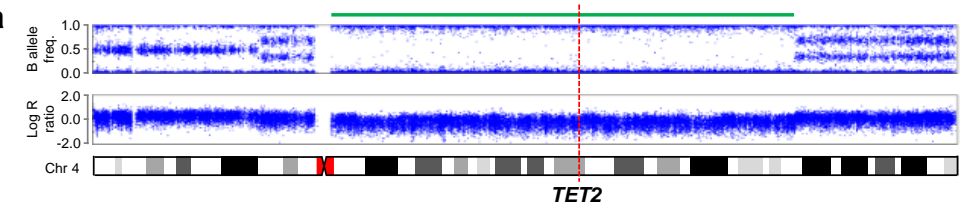

b
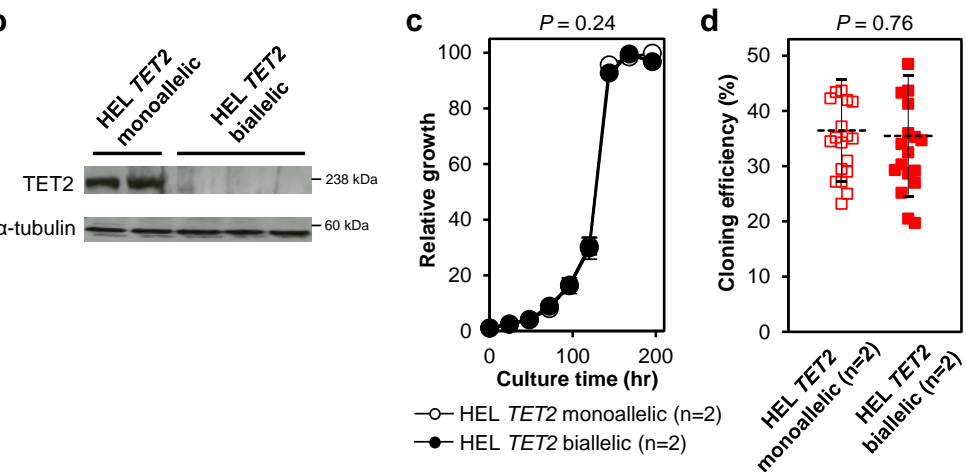

e

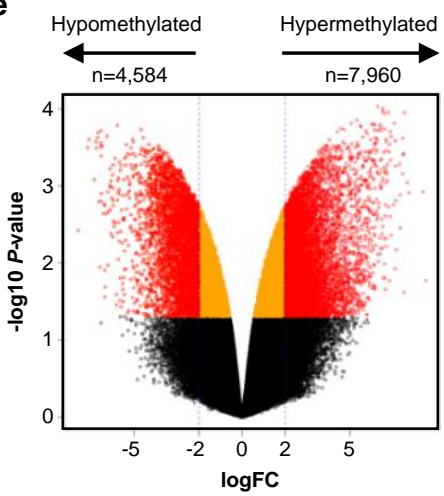

f

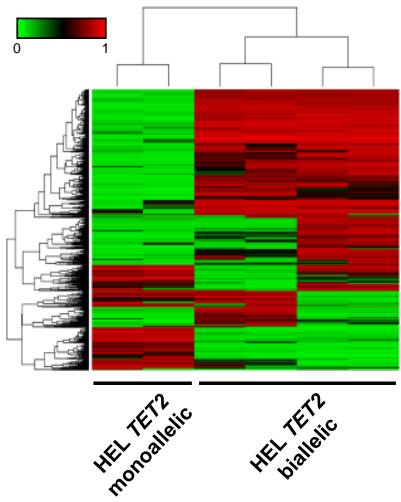

Figure 2. Complete loss of TET2 expression confers a hypermethylation phenotype.

(a) High density array copy number profile of chromosome 4 from HEL cells showing large deletion (green bar) affecting the $\mathrm{q}$ arm, including TET2 (position indicated by dashed red line). (b) Immunoblot showing TET2 protein expression in two representative parental TET2 monoallelic HEL cell clones (HEL TET2 monoallelic) and three representative TET2 CRISPR-Cas9mutated HEL cell clones (HEL TET2 biallelic). $\alpha$-tubulin was used as loading control. (c) Growth kinetics in suspension culture of HEL TET2 monoallelic (open circles) and HEL TET2 biallelic (filled circles) cell clones. Cells were seeded at low density and growth (relative to initial density) was determined at regular intervals. Data represents mean and SD of indicated number of clones from three independent experiments. $P$ value calculated by one-way ANOVA. (d) CE was calculated for HEL TET2 monoallelic (open squares) and HEL TET2 biallelic (filled squares) clones after 30 days culture in soft agar. Mean and SD of indicated number of clones from seven independent experiments are shown. $P$ value calculated by 2-tailed Student's t-test. (e) Volcano plot demonstrating differences in CpG methylation between HEL TET2 monoallelic ( $\mathrm{n}=2$ ) and HEL TET2 biallelic ( $\mathrm{n}=4$ ) clones. Plot was constructed using fold-change $\left(\log _{2} \mathrm{FC}\right)$ values and adjusted $P$-values and points represent individual $\mathrm{CpG}$ probes, colored such that significantly differentially methylated probes $\left(P<0.05\right.$ and $\left.\left|\log _{2} \mathrm{FC}\right| \geq 2\right)$ are in red. Orange points represent probes which reach significance $(P<0.05)$ but are not differentially methylated $\left(\left|\log _{2} \mathrm{FC}\right|<2\right)$ and black points represent non-significant $(P \geq 0.05)$ probes. (f) Unsupervised hierarchical clustering of the top 1,500 differentially methylated CpG probes across all samples resulted in distinct clustering of parental HEL TET2 monoallelic $(\mathrm{n}=2)$ and HEL TET2 biallelic ( $\mathrm{n}=4)$ cell clones. Rows in the heatmap represent $\mathrm{CpG}$ probes and vertical columns are cell clones. Color key indicates level of methylation at CpGs. 
medRxiv preprint doi: https://doi.org/10.1101/2021.07.14.21259597; this version posted July 18, 2021. The copyright holder for this preprint (which was not certified by peer review) is the author/funder, who has granted medRxiv a license to display the preprint in perpetuity. Figutrẹ made available under a CC-BY 4.0 International license.

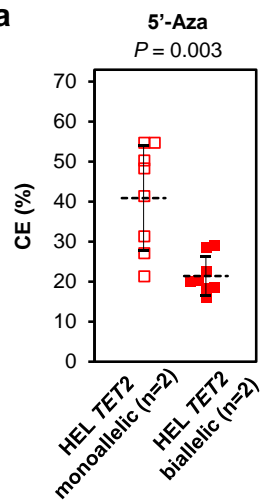

b

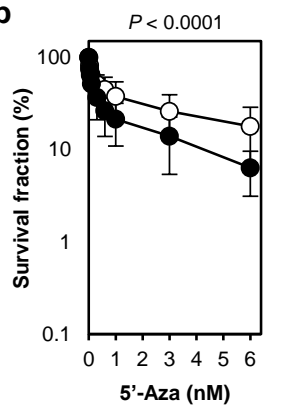

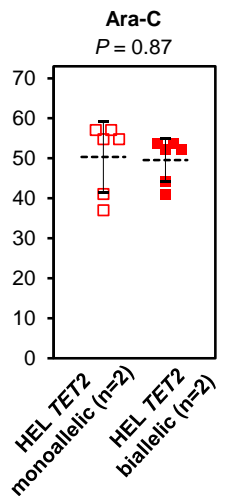

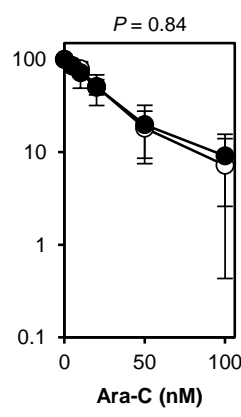

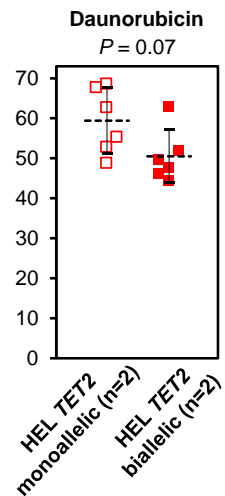

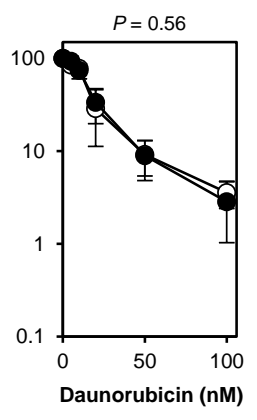

C
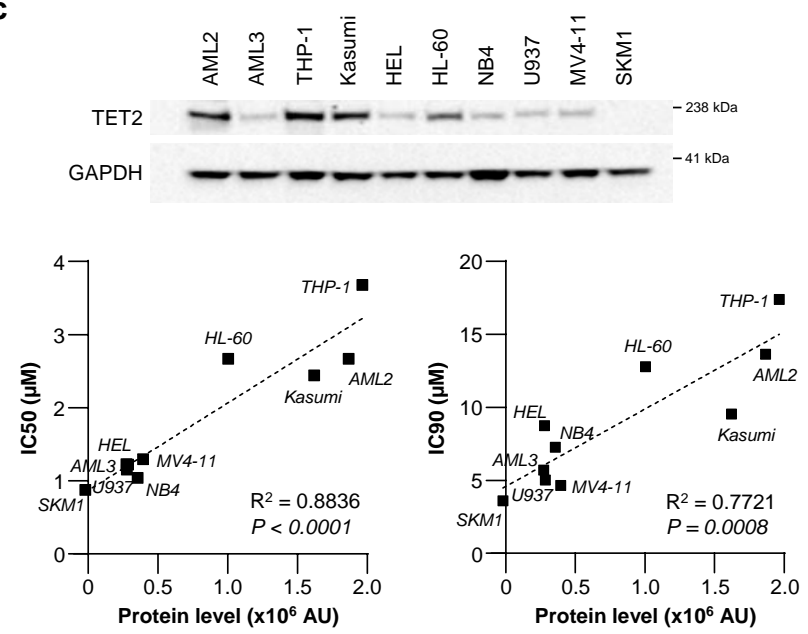

Figure 3. Cells with biallelic TET2 mutations are sensitive to the hypomethylating agent, 5'-Aza in in vitro model systems. (a) Parental TET2 monoallelic HEL cell clones (HEL TET2 monoallelic; open squares) and TET2 CRISPR-Cas9-mutated HEL cell clones (HEL TET2 biallelic; filled squares) were cultured in soft agar supplemented with 1nM 5'-Aza (left), 20nM Ara-C (center) or 20nM daunorubicin (right) and CE (relative to respective vehicle control-treated cells) was determined after 30 days. Mean and SD of indicated number of clones from three independent experiments are shown. $P$ values calculated by Student's ttest (2-tailed). (b) Parental TET2 monoallelic HEL cell clones (HEL TET2 monoallelic; open circles) and TET2 CRISPR-Cas9mutated HEL cell clones (HEL TET2 biallelic; filled circles) were treated with 5'-Aza (left), Ara-C (center) or daunorubicin (right) and cell density (relative to respective vehicle control-treated cells) was determined after 96 hrs. Data represents mean and SD of indicated number of clones from three independent experiments. $P$ values calculated by two-way ANOVA. (c) Western blot (top panel) showing TET2 protein expression in a panel of 10 AML cell lines. GAPDH was used as a loading control. TET2 protein expression was quantified in each cell line and plotted against 5'-Aza IC50 (left) and IC90 (right) values. AU represents arbitrary units as measured by the Fuji LAS-300 Image Analyzer System. 
medRxiv preprint doi: https://doi.org/10.1101/2021.07.14.21259597; this version posted July 18, 2021. The copyright holder for this preprint (which was not certified by peer review) is the author/funder, who has granted medRxiv a license to display the preprint in perpetuity. It is made available under a CC-BY 4.0 International license .

Figure 4

a

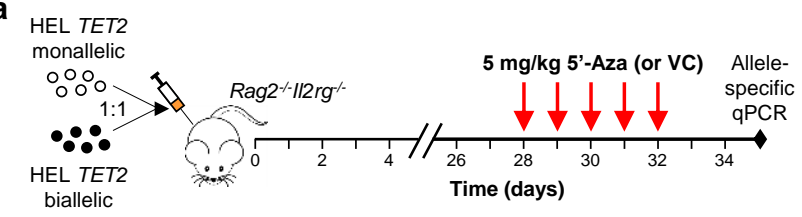

b

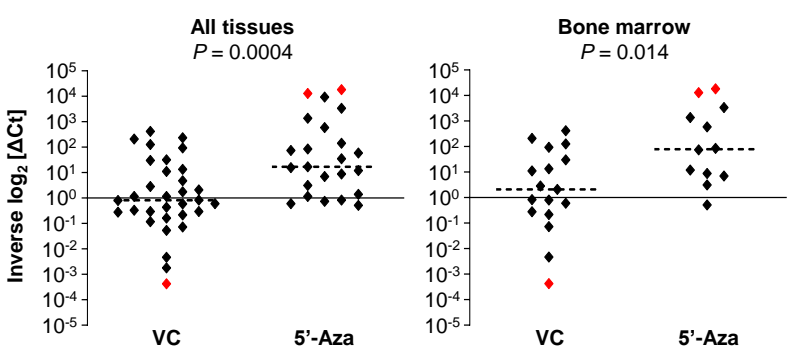

Figure 4. Cells with biallelic TET2 mutations are subject to 5'-Aza-induced negative selection in an orthotopic AML mouse model.

(a) Schematic of orthotopic AML mouse model. HEL TET2 monoallelic and HEL TET2 biallelic cell clones were co-injected in a 1:1 ratio into the femurs of $\mathrm{Rag}^{-/-} \mathrm{Il}_{2} \mathrm{rg}^{-/-}$mice. Treatment with 5 -Aza (5mg/kg daily for 5 days) or VC was initiated on day 28 (post-injection) and tissues were harvested on day 35 for TET2 allele-specific qPCR analysis. (b) Tissue samples collected from mice were analyzed by custom TET2 allele-specific qPCR assay. Shown are inverse $\log _{2}[\Delta C \mathrm{Ct}]$ values which represent relative expression of the WT versus the $4 \mathrm{bp}$ deleted TET2 allele in individual samples, and are the means of triplicate reactions. Inverse $\log _{2}[\Delta \mathrm{Ct}]$ of 1 indicates a 1:1 ratio between the WT and 4bp deleted TET2 alleles (and hence HEL TET2 monoallelic and HEL TET2 biallelic clones), whereas inverse $\log _{2}[\Delta \mathrm{Ct}]>1$ or inverse $\log _{2}[\Delta \mathrm{Ct}]<1$ indicates dominance of the WT (HEL TET2 monoallelic) or 4bp deleted (HEL TET2 biallelic) allele, respectively. Red points indicate samples which were dominated entirely by one cell clone. Horizontal dashed lines represent median inverse $\log _{2}[\Delta \mathrm{Ct}]$ values across all samples from $\mathrm{VC}$ - or 5'-Azatreated mice. The left panel shows data from all harvested tissues (BM, PB, spleen and tumors) and the right panel shows data from BM only. $P$ values comparing inverse $\log _{2}[\Delta \mathrm{Ct}]$ values from VC and 5'-Aza-treated mice were calculated using a MannWhitney test. 
medRxiv preprint doi: https://doi.org/10.1101/2021.07.14.21259597; this version posted July 18, 2021. The copyright holder for this preprint (which was not certified by peer review) is the author/funder, who has granted medRxiv a license to display the preprint in perpetuity. Figure 5

a

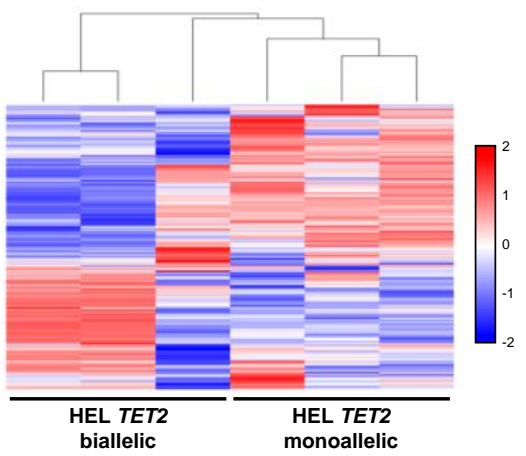

b

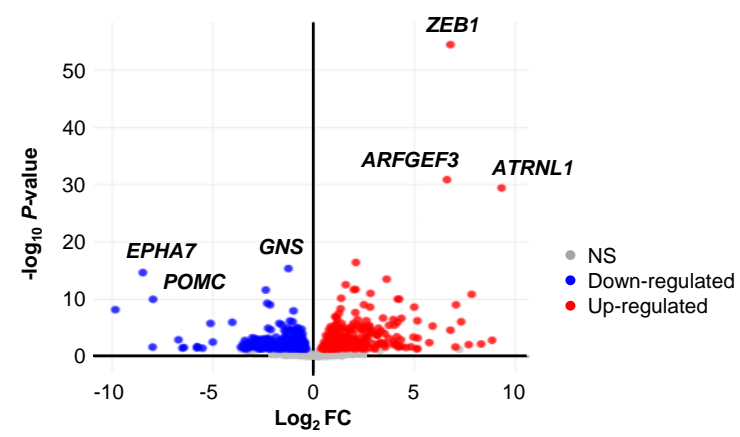

C

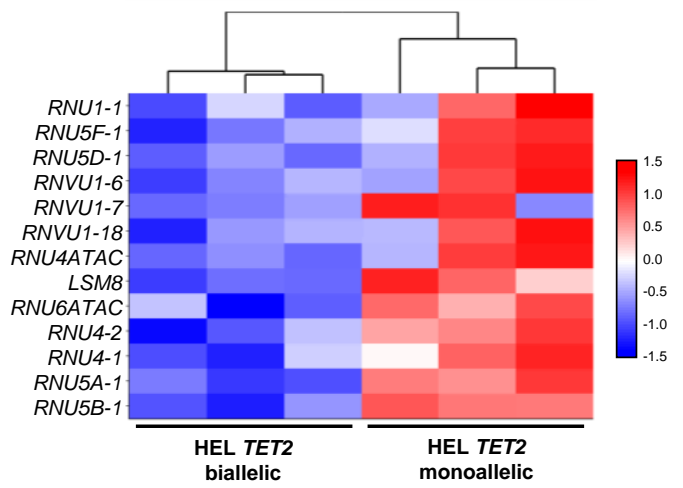

d
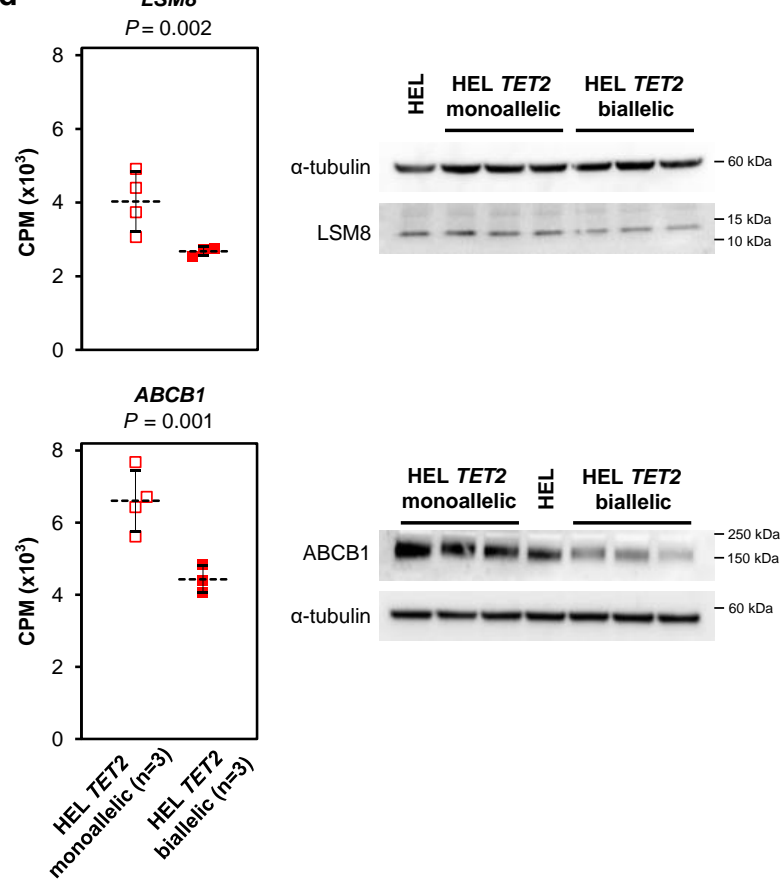

Figure 5. Differential gene expression in AML cells with monoallelic and biallelic TET2 mutations.

(a) Unsupervised heirarchical clustering of the top 1,500 differentially expressed transcripts in parental TET2 monoallelic HEL cell clones (HEL TET2 monoallelic; $\mathrm{n}=3$ ) and TET2 CRISPR-Cas9-mutated HEL cell clones (HEL TET2 biallelic; $n=3$ ). Horizontal rows of the heatmap represent individual transcripts and each vertical column is a cell clone. Color indicates relative expression with down-regulated and up-regulated transcripts indicated in blue and red, respectively. (b) Volcano plot demonstrating significant differential gene expression $(P$ value $<0.05$ and $\left.\left|\log _{2} \mathrm{FC}\right| \geq 0.3\right)$ in TET2 CRISPR-Cas9mutated HEL cell clones (HEL TET2 biallelic; $n=3$ ) relative to parental HEL clones with monoallelic TET2 mutation (HEL TET2 monoallelic; $\mathrm{n}=3$ ). Plot was constructed using fold-change ( $\log _{2}$ FC) values and adjusted $P$-values and points represent individual gene transcripts. Shown are 326 significantly down-regulated transcripts (blue) and 369 significantly up-regulated transcripts (red). Non-significant (NS) transcripts $(P$ value $\geq 0.05$ ) are represented by grey points. Genes with particularly significant differential expression are labelled. (c) Heatmap showing differential expression of components of the spliceosomal snRNP complex (GO:009752) in parental TET2 monoallelic HEL cell clones (HEL TET2 monoallelic; $\mathrm{n}=3$ ) and TET2 CRISPRCas9-mutated HEL cell clones (HEL TET2 biallelic; $n=3$ ). Horizontal rows represent genes and each vertical column is a cell clone. Color indicates relative expression, as in (a). (d) Transcript expression (expressed as counts per million (CPM) reads) of LSM8 (top) and $A B C B 1$ (bottom) in parental TET2 monoallelic HEL cell clones (HEL TET2 monoallelic; open bars) and TET2 CRISPR-Cas9-mutated HEL cell clones (HEL TET2 biallelic; filled bars). Data represents the mean and SD of indicated number of clones. $P$ values are from differential expression analysis. Western blots to the right of the charts show corresponding protein expression in the individual cell clones included in RNA sequencing analysis. $\alpha$-tubulin was used as a loading control. 
medRxiv preprint doi: https://doi.org/10.1101/2021.07.14.21259597; this version posted July 18, 2021. The copyright holder for this preprint (which was not certified by peer review) is the author/funder, who has granted medRxiv a license to display the preprint in perpetuity. It is made available under a CC-BY 4.0 International license.

Figure 6

a

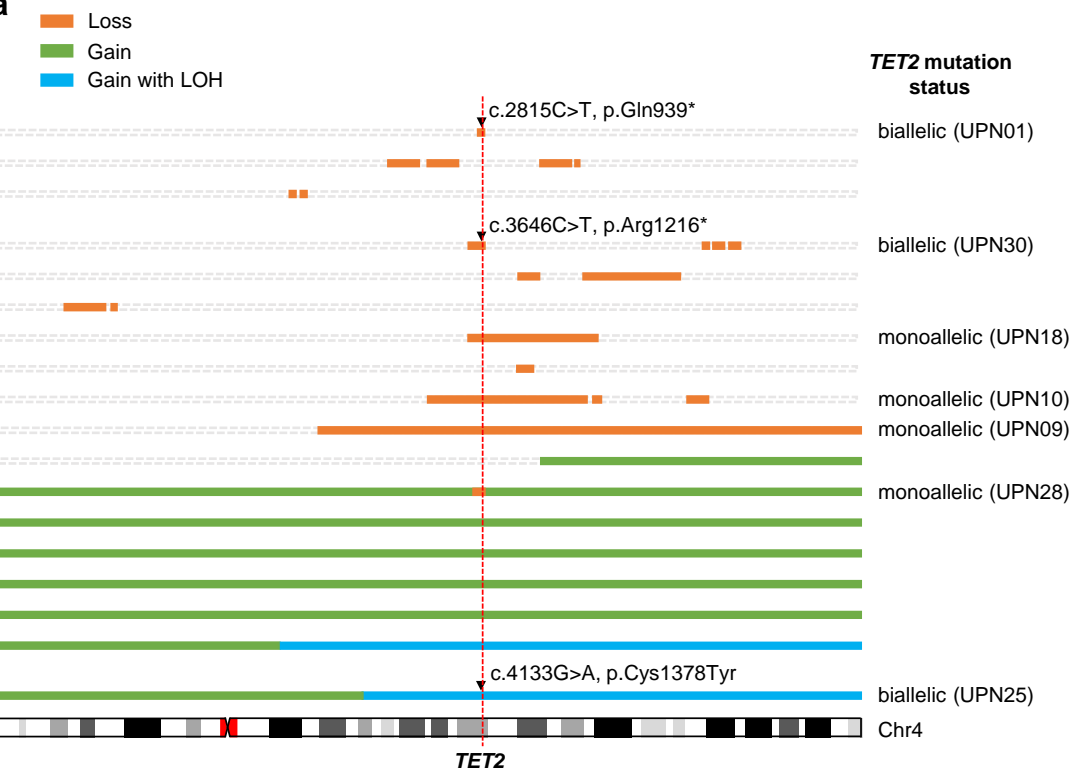

b
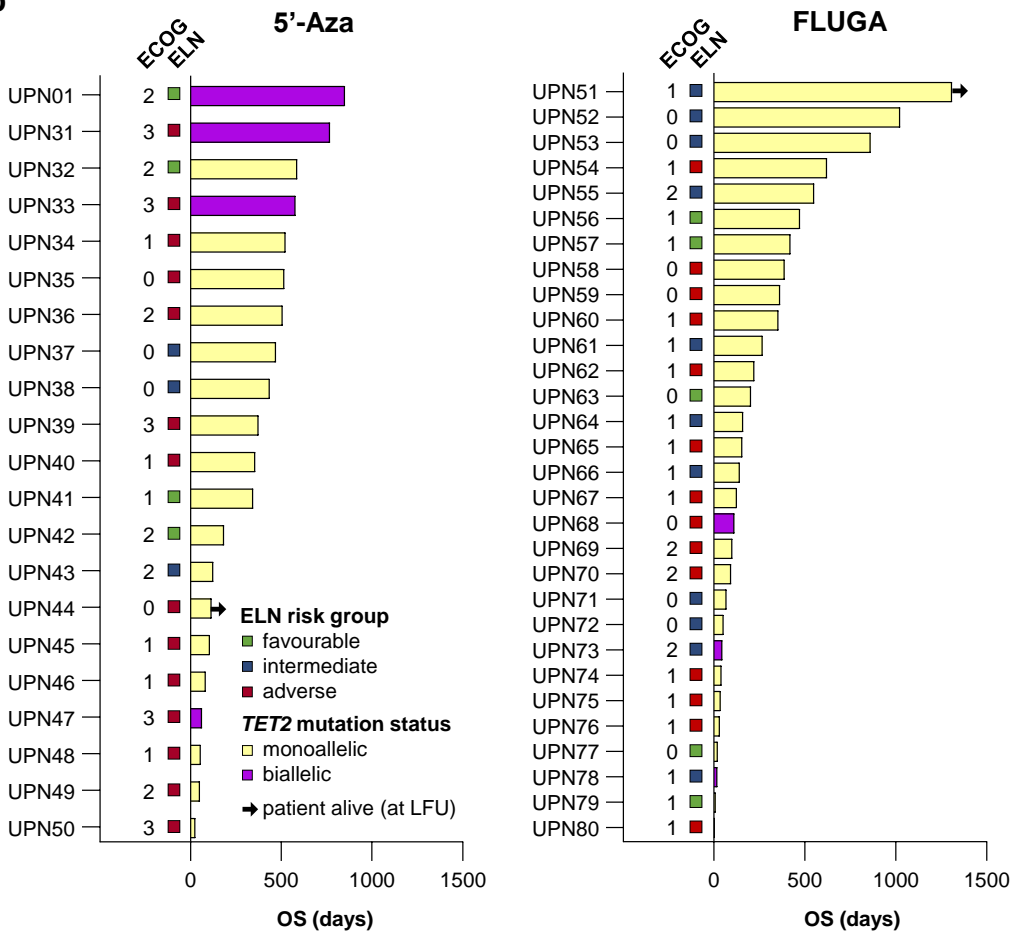

Figure 6. Somatic mutations affecting the TET2 locus in AML patients with cytogenetic abnormality of chromosome 4 and response to treatment in AML patients with TET2 mutation.

(a) Illustrated are regions of copy number gain (green), gain with concomitant LOH (blue) and loss (orange) affecting chromosome 4 (discerned using high-density SNP array) in 18 AML patients with cytogenetically detectable abnormalities of chromosome 4. Base substitution mutations (indicated by black triangles) were determined by TET2 exon sequencing. The vertical dashed red line indicates the location of the TET2 gene. The mutation status of the 7 patients with loss of function TET2 mutations are indicated to the right. Patient ID numbers are shown in parentheses for these patients. (b) Swimmer plots showing patients with TET2 mutated AML treated with either 5'-Aza (left) or low-dose Ara-C plus fludarabine (FLUGA) (right). The AML index case (UPN01) is included in the 5'-Aza swimmer plot for reference. Patients with biallelic TET2 mutation (UPN01, UPN31, UPN33, UPN47, UPN68, UPN73 and UPN78) are represented by purple bars. All other patients had monoallelic TET2 mutation discerned by whole exome sequencing and are represented by pale yellow bars. European LeukemiaNet (ELN) favorable, intermediate and adverse risk groups are represented by green, blue and red squares, respectively. ECOG, Eastern Cooperative Oncology Group performance score. 